\title{
Does roflumilast induce phagocytic activity in COPD patients?
}

\author{
This article was published in the following Dove Press journal: \\ International Journal of COPD \\ II September 2015 \\ Number of times this article has been viewed
}

\section{Baishakhi Ghosh ${ }^{1,2}$ \\ Nitin V Vanjare'}

'Chest Research Foundation (CRF), Pune, Maharashtra, India; ${ }^{2}$ Faculty of Health and Biomedical Science (FOHBS), Symbiosis International University, Pune, Maharashtra, India
Correspondence: Baishakhi Ghosh Chest Research Foundation (CRF), Survey No 15, Marigold Complex, Kalyaninagar, Pune 4II0I4,

Maharashtra, India

Tel +9| $8884 \mid 37598$

Fax+9| $202703537 \mid$

Email bghosh226@gmail.com

\section{Dear editor}

We read the article by Porpodis et al ${ }^{1}$ with great interest. In this study, the authors have evaluated the effect of roflumilast on the phagocytic activity of systemic phagocytes in severe and very severe COPD patients by measuring the oxidative burst post-bacterial stimulation. The study group for this study involved 21 severe or very severe COPD patients who were administered roflumilast in addition to other COPD treatments such as long-acting beta-adrenoceptor agonists (LABA) + inhaled corticosteroids (ICS) + long-acting anti-muscarinic agent (LAMA) or ICS + LABA.

Prior animal studies have reported that ICS impairs Klebsiella pneumoniae phagocytosis and decreases oxidative stress post-infection with bacteria. ${ }^{2}$ It would have been interesting to know the phagocytic efficacy of roflumilast in combination with other therapeutic drugs for instance, whether the phagocytic efficacy of the combination of roflumilast and ICS is more as compared to other combinations. This could have been possibly achieved by dividing the study group into subgroups such as ICS + roflumilast or LABA + roflumilast or LAMA + roflumilast or ICS + LABA + roflumilast. Porpodis et $\mathrm{al}^{1}$ also reported that roflumilast increases phagocytic activity, and this anti-inflammatory effect contributes toward increase in lung function parameters among COPD subjects. ${ }^{3}$ Previous studies have reported that ICS + LABA or ICS + LABA + LAMA improves the lung function. However, in this study there is no control group (group without roflumilast treatment) therefore, the improvement seen in lung function could be a combined effect of ICS + LABA, ICS + LABA + LAMA and roflumilast and not roflumilast alone.

Additionally, it would have been interesting to know whether increase in phagocytosis by roflumilast can contribute toward improvement of exacerbations. It has been reported by Calverley et $\mathrm{al}^{4}$ that roflumilast decreases exacerbations among mild to moderate COPD patients, but there are no data available with reference to severe COPD patients. Lastly, the authors should have presented the lung function data in terms of actual values along with the percent predicted format, this would have made the results easy to comprehend.

\section{Disclosure}

The authors have no conflicts of interest to disclose.

\section{References}

1. Porpodis K, Domvri K, Zarogoulidis P, et al. Roflumilast, a phosphodiesterase-4 inhibitor, induces phagocytic activity in Greek COPD patients. Int J Chron Obstruct Pulmon Dis. 2015;10:1123-1128.

2. Patterson CM, Morrison RL, D'Souza A, Teng XS, Happel KI. Inhaled fluticasone propionate impairs pulmonary clearance of Klebsiella pneumoniae in mice. Respir Res. 2012;13(1):40. 
3. Tashkin DP, Ferguson GT. Combination bronchodilator therapy in the management of chronic obstructive pulmonary disease. Respir Res. 2013;14(1):49.
4. Calverley PM, Rabe KF, Goehring UM, et al. Roflumilast in symptomatic chronic obstructive pulmonary disease: two randomised clinical trials. Lancet. 2009;374(9691):685-694. 


\section{Authors' reply}

Paul Zarogoulidis

Konstantinos Zarogoulidis

Pulmonary Department, Oncology Unit, "G Papanikolaou” General Hospital, Aristotle University of Thessaloniki, Thessaloniki, Greece

Correspondence: Paul Zarogoulidis

Pulmonary Department, Oncology Unit,

"G Papanikolaou" General Hospital,

Aristotle University of Thessaloniki, 57010, Thessaloniki 57010, Greece

Tel +30 6977271974

Fax +302310992424

Email pzarog@hotmail.com

\section{Dear editor}

We chose outpatients from our clinic who were stable for at least a month. Seven days before roflumilast treatment these patients were monitored more frequently. They all had a history of exacerbations but no one was recovering from an acute exacerbation.

We included a table with patients' characteristics (Table 1). No patient was taking oral steroids during the study period. Patients were treated according to TORCH (Towards a Revolution in Chronic Obstructive Pulmonary Disease Health) and UPLIFT (Understanding Potential Long-term Impacts on Function with Tiotropium) studies. Our hypothesis was that the addition of an anti-inflammatory
Table I Patients' characteristics

\begin{tabular}{ll}
\hline Characteristics & $\begin{array}{l}\text { No \% of patients } \\
(\mathbf{N}=\mathbf{2} \text { I) }\end{array}$ \\
\hline Age, years (mean) & 67.4 \\
Sex (male, female) & $(86 \%, 14 \%)$ \\
Groups (C, D) & $(72 \%, 28 \%)$ \\
LABA + ICS + LAMA, LABA + ICS & $(28 \%, 72 \%)$ \\
Frequency of exacerbations (I, 2) & $(80 \%, 20 \%)$ \\
FEV, \% pred (mean) & $42.3 \%$ \\
FVC \% pred (mean) & $63.5 \%$ \\
\hline
\end{tabular}

Abbreviations: LABA, long-acting beta-adrenoceptor agonists; ICS, inhaled corticosteroids; LAMA, long-acting anti-muscarinic agent; pred, predicted; FEV forced expiratory volume in I second; FVC, forced vital capacity.

regimen such as roflumilast, in patients who experience frequent exacerbations, would have beneficial influence on lung function and exacerbations. This is the only way to be sure that the PDE-4 inhibitor induces phagocytic activity and to what degree. If an oral corticosteroid had been used we would not be sure if PDE-4 would assist in the treatment of an exacerbations. Due to the small number of patients, statistical analysis by subgrouping the patients was not possible. Every patient was a control to himself and every spirometry value or phagocytic activity was compared to the first values before roflumilast treatment. Our study is an on-going pilot study. Although COPD care has improved over the last decade, ${ }^{1}$ there is still a huge unmet burden of disease. Exacerbations

\section{$95 \% \mathrm{Cl}$ for the mean}
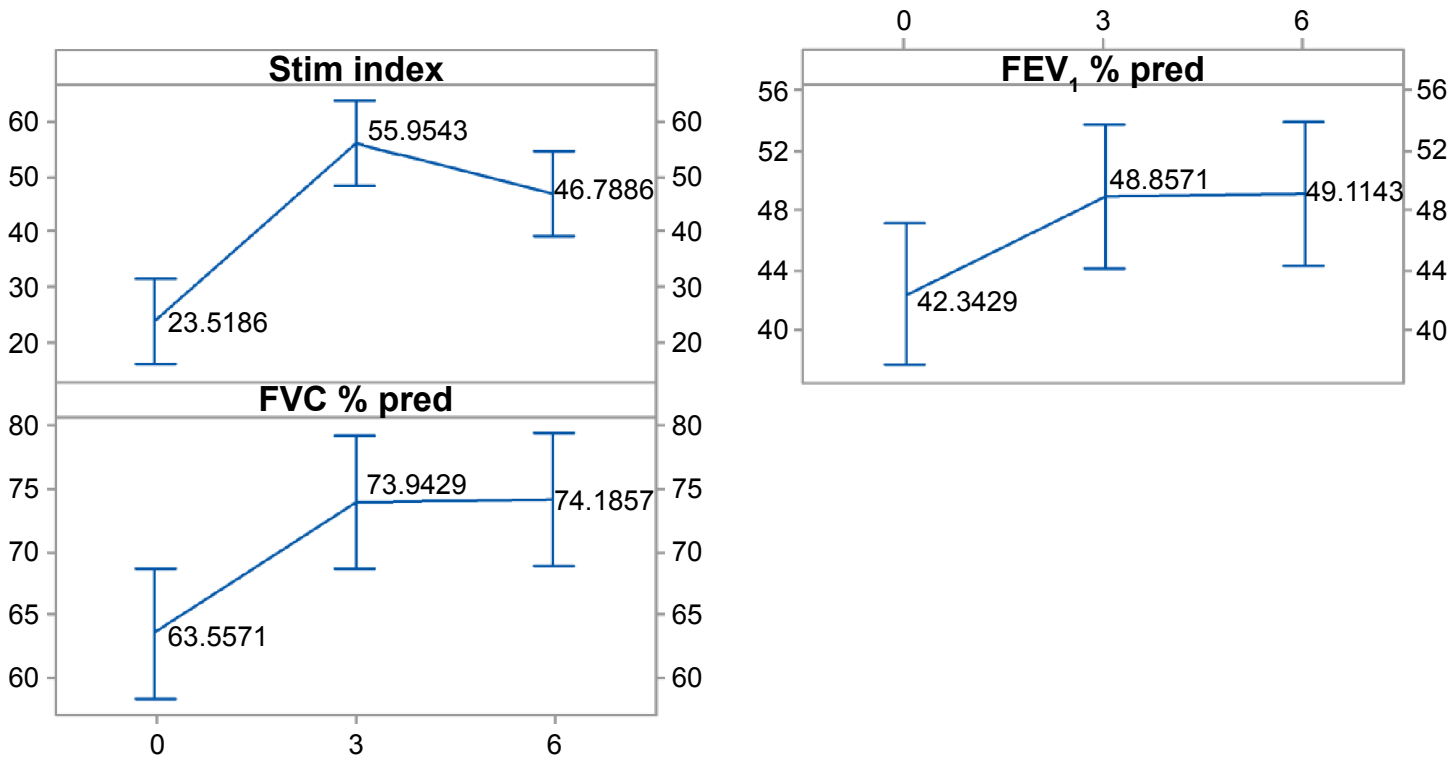

\section{Months}

Figure I Mean change of stimulation index (phagocytic activity), FEV, \% predicted, FVC \% predicted, per indicated periods (0: before receiving roflumilast, 3 months and 6 months after).

Notes: Vertical bars represent the $95 \%$ confidence intervals of means calculated from analysis of variance error mean square. The pooled standard deviation was used to calculate the intervals.

Abbreviations: pred, predicted; $\mathrm{FEV}_{1}$, forced expiratory volume in I second; $\mathrm{FVC}$, forced vital capacity; $\mathrm{Cl}$, confidence interval; stim, stimulation. 
in particular can be distressing for patients ${ }^{2}$ and have serious consequences on their long-term health, such as increased disease progression, ${ }^{3}$ increased risk of cardiovascular events, ${ }^{4}$ and increased mortality rates. ${ }^{5,6}$ Roflumilast is an oral PDE-4 inhibitor that targets inflammatory cells involved in triggering COPD exacerbations. It includes the only PDE-4 inhibitor approved by the US Food and Drug Administration and is available in $500 \mu \mathrm{g}$ tablets to be administered once daily. As stated in our publication although this was a small study, the anti-inflammatory activity of roflumilast was shown to provide incremental benefits on top of existing therapies. Future randomized studies will further confirm the impact of roflumilast on COPD and beyond. The authors believe that the lung function values would not clearly present the changes and therefore we chose to present this information with the variability of the values (Figure 1).

\section{Disclosure}

The authors have no conflicts of interest to disclose.

\section{References}

1. Almagro P, Salvado M, Garcia-Vidal C, et al. Recent improvement in long-term survival after a COPD hospitalisation. Thorax. 2010;65(4): 298-302.

2. Kessler R, Stahl E, Vogelmeier C, et al. Patient understanding, detection, and experience of COPD exacerbations: an observational, interviewbased study. Chest. 2006;130(1):133-142.

3. Decramer M, Cooper CB. Treatment of COPD: the sooner the better? Thorax. 2010;65(9):837-841.

4. Donaldson GC, Hurst JR, Smith CJ, Hubbard RB, Wedzicha JA. Increased risk of myocardial infarction and stroke following exacerbation of COPD. Chest. 2010;137(5):1091-1097.

5. Wedzicha JA, Seemungal TA. COPD exacerbations: defining their cause and prevention. Lancet. 2007;370(9589):786-796.

6. Soler-Cataluna JJ, Martinez-Garcia MA, Roman Sanchez P, Salcedo E, Navarro M, Ochando R. Severe acute exacerbations and mortality in patients with chronic obstructive pulmonary disease. Thorax. 2005;60(11): 925-931.

Dove Medical Press encourages responsible, free and frank academic debate. The content of the International Journal of Chronic Obstructive Pulmonary Disease 'letters to the editor' section does not necessarily represent the views of Dove Medical Press, its officers, agents, employees, related entities or the International Journal of Chronic Obstructive Pulmonary Disease editors. While all reasonable steps have been taken to confirm the content of each letter, Dove Medical Press accepts no liability in respect of the content of any letter, nor is it responsible for the content and accuracy of any letter to the editor.

\section{Publish your work in this journal}

The International Journal of COPD is an international, peer-reviewed journal of therapeutics and pharmacology focusing on concise rapid reporting of clinical studies and reviews in COPD. Special focus is given to the pathophysiological processes underlying the disease, intervention programs, patient focused education, and self management protocols.

\section{Dovepress}

This journal is indexed on PubMed Central, MedLine and CAS. The manuscript management system is completely online and includes a very quick and fair peer-review system, which is all easy to use. Visit $\mathrm{http} / / / \mathrm{www}$.dovepress.com/testimonials.php to read real quotes from published authors. 